\title{
Effect of pre-harvest spray of calcium nitrate, boric acid and zinc sulphate on yield and quality of Nagpur mandarin (Citrus reticulata Blanco)
}

\author{
Meena, M. K., Jain, M.C., Singh, J., Sharma, M., Singh, B. \& Maurya, I.B. \\ Department of Fruit Science, College of Horticulture and Forestry, \\ Jhalarapatan city, Jhalawar-326023 (Rajasthan) \\ Agriculture University, Kota (Rajasthan) \\ E-mail-manishkhamrya@gmail.com
}

\begin{abstract}
Summary: An investigation was conducted on uniform, healthy, eight year old trees of Nagpur mandarin (citrus reticulata Blanco) at Fruit Research Farm, Department of Fruit Science at College of Horticulture and Forestry, Jhalawar during 16 September, 2014 to 1 March, 2015. Various doses of calcium nitrate $(1.0 \%, 2.0 \%$ and $3.0 \%)$, boric acid $(0.2 \%, 0.4 \%$ and $0.6 \%)$ and zinc sulphate $(0.2 \%, 0.4 \%$ and $0.6 \%)$ were sprayed before harvesting and compared with untreated ones. The results obtained indicated that the trees sprayed with $\mathrm{T}_{27}$ i.e. (calcium nitrate $3.0 \%$ + boric acid $0.6 \%$ + zinc sulphate $0.6 \%$ ) showed maximum increase diameter of fruit, fruit weight, fruit volume, number of fruits per plant, fruit yield per plant, estimated yield per hectare, reducing sugar, non reducing sugar, total sugar, juice per cent, sensory score and reduced peel thickness over control. Further, $\mathrm{T}_{24}$ treatment combination (calcium nitrate $3.0 \%+$ boric acid $0.4 \%+$ zinc sulphate $0.6 \%$ ) has also significantly increased number of segments per fruit, TSS, TSS: Acid ratio, ascorbic acid content, and reduced number of seeds per fruit and acidity percent of fruits.
\end{abstract}

Keywords: pre-harvest spray, calcium nitrate, zinc sulphate, boric acid, yield, quality

\section{Introduction}

Mandarin is considered to be one of the most important cultivated species among citrus groups. Nagpur mandarin (Citrus reticulata Blanco) belongs to family Rutaceae. Among the various citrus species, mandarin, sweet orange and lime are the common citrus fruits having 50, 21 and 15 per cent of total area under them, respectively. Nagpur mandarin is being commercially grown in specific region of the country like Nagpur mandarin in Central India, Khasi mandarin in North Eastern regions and Coorg mandarin in Southern regions. The total production of mandarin in India is 34.31 lakh tonnes from an area of 330.0 thousand hectares with the productivity of $10.4 \mathrm{~m} \mathrm{t} /$ ha (Anonymous, 2015). In Rajasthan mandarin covers 11.20 thousand hectares area producing 229.90 thousand MT with the productivity of 20.5 $\mathrm{m} \mathrm{t} /$ ha (Anonymous, 2015). In the state, In Jhalawar district mandarin where it is grown over 37,251 ha area, 11,323 ha of which are in the fruit bearing stage and the production is 2.5 Lac tonnes (Anonymous, 2015).

The nutrient plays an important role in the development and growth of new cells in plant meristem. The calcium salts are known to be involved in a number of physiological processes concerning membrane structure, function and enzymatic activity. The exact role of calcium, like that of all minerals, is still obscure, but it is important for cell wall development (Katiyar et al. 2008; Holb et al., 2012). Zinc $(\mathrm{Zn})$ is an essential micro element for plants, being involved in many enzymatic reactions and is necessary for their good growth and development (Razzaq et al. (2013). Boron is also a heavy metal micronutrient. It is essential for translocation of sugar; involved in reproduction of plants and germination of pollen grains (Chaturvedi et al. (2007).

Since the demand of fruit is increasing in the market, thereby to achieve higher yield of good quality fruit with longer storage life become the priority. To improve the quality of fruit at harvest and to enhance the storage life by influencing the after harvest changes, several research workers have used certain pre-harvest treatments. The application of mineral nutrients like calcium nitrate, boric acid and zinc sulphate are known to play a crucial role in growth, development, quality and storage of fruits.The present study will contribute in understanding the physical and biochemical status of Nagpur mandarin fruits at harvest as influenced by pre-harvest spray of mineral nutrients, which may help in increasing the yield, quality of Nagpur mandarin. Hence the present studies were undertaken under Rajasthan conditions especially in Jhalawar with the followings objectives: 1 . to study the effect of calcium nitrate, boric acid and zinc sulphate on yield and quality attributing characters of nagpur mandarin; 2 . to study 
the effect of calcium nitrate, boric acid and zinc sulphate on storability parameters of nagpur mandarin; 3 . to study the economics of the treatments used.

\section{Materials and methods}

The present investigation was carried out on eight years old Nagpur mandarin (Citrus reticulata Blanco.) of uniform size and growth at the Fruit research farm, Department of Fruit Science, College of Horticulture and Forestry, Jhalawar during the year 2014-15. The selected plants were sprayed with Calcium nitrate (1.0, 2.0 and 3.0 per cent), Boric acid (0.2, 0.4 and 0.6 per cent) and Zinc sulphate $(0.2,0.4$ and 0.6 per cent).This experiment was laid out in Factorial Randomized Block Design (RBD) with three replications. The factors of experimentation comprising of 28 treatment combinations to study the effect of pre-harvest spray of calcium nitrate, zinc sulphate and boric acid on yield, quality and storability of Nagpur mandarin (Citrus reticulata Blanco). The treatments were applied during second week of September, 2014 after selection of good uniform size and bearer plant. The observations were recorded on different aspects viz. physical characteristics of fruits (diameter of fruit, peel thickness, fruit weight, fruit volume, number of fruits per plant, number of sacs per fruit, number of seeds per fruit. The chemical composition of Nagpur mandarin fruits with respect to total soluble solids (TSS), total sugar, titrable acidity, ascorbic acid contents were determined by (AOAC 2007) by taking the samples from extracted juice of fruits. The data generated during the experimentation were subjected to statistical analysis of variance. The significance of the treatments was tested through ' $F$ ' test at 5 per cent level of significance. The critical difference was calculated to assess the significance of difference among the different treatments as described by fisher (1950).

\section{Result and discussion}

The data in (Table 1) reveal that interaction effect of calcium nitrate, boric acid and zinc sulphate was significant on diameter of fruits. The maximum increase in horizontal diameter $(7.89 \mathrm{~cm})$ and vertical diameter $(7.58 \mathrm{~cm})$ was observed with treatment $\mathrm{T}_{27}$ (calcium nitrate $3.0 \%+$ boric acid $0.6 \%+$ zinc sulphate $0.6 \%$ ), which was closely followed by $\mathrm{T}_{23}, \mathrm{~T}_{26}, \mathrm{~T}_{24}, \mathrm{~T}_{22}$ and $\mathrm{T}_{21}$ treatments. The higher fruit diameter due to combined application of calcium, boron and zinc may be attributed to their stimulatory effect of plant metabolism and better increase in cell division and cell elongation of cells. The results are in conformity with the observations recorded by Tariq et al.(2007) in Sweet orange and Razzaq et al. (2013) in Kinnow.

The data in (Table 1) reveal that interaction effect of calcium nitrate, boric acid and zinc sulphate was significantly observed on peel thickness. The minimum peel thickness (3.21 $\mathrm{mm}$ ) of fruit was recorded with the treatment $\mathrm{T}_{27}$ (calcium nitrate $3.0 \%+$ boric acid $0.6 \%+$ zinc sulphate $0.6 \%$ ) and which was closely followed by $\mathrm{T}_{24}, \mathrm{~T}_{26}, \mathrm{~T}_{22}$ and $\mathrm{T}_{25}$ treatments. However, the maximum peel thickness of fruit $(4.86 \mathrm{~mm})$ was recorded under control. The reduction in peel thickness might be attributes to the effect of zinc sulphate and prevailing climate condition during harvesting of fruit. The present results are in close conformity with the finding of Haque et al. (2000) in Mandarin and Patil et al. in Kinnow (2014).

The data in (Table 1) narrate that fruit weight and fruit volume of Nagpur mandarin increased significantly by the application of calcium nitrate, boric acid and zinc sulphate. The maximum fruit weight (160.72 g) and volume (190.14 cc) were recorded with treatment $\mathrm{T}_{27}$ (calcium nitrate $3.0 \%$ + boric acid $0.6 \%$ + zinc sulphate $0.6 \%$ ). The minimum fruit weight and volume $(113.61 \mathrm{~g})$ and $138.03 \mathrm{cc})$ were measured under control. The increase in fruit weight and volume might be due to increased rate of cell division and cell enlargement leading to more accumulation of metabolites in the fruit and better translocation of photosynthates as a result of boron application (Abd-Allah (2006). The findings are similar to those reported by Babu et al. (2007) in Kinnow and Meena et al. (2014) in Guava.

The data in (Table 2) reveal that interaction effect of calcium nitrate, boric acid and zinc sulphate was significant on number of seeds per fruit. The minimum number of seeds per fruit (6.33) was recorded with treatment $\mathrm{T}_{24}$ (calcium nitrate 3 per cent + boric acid 0.4 per cent + zinc sulphate 0.6 per cent) which was closely followed by $T_{27}, T_{26}, T_{21}, T_{22}$ and $T_{23}$ treatments. However, the maximum number of number of seed per fruit (9.89) was recorded in control. The present results are in consonance with the findings of Haque et al. (2000) in Mandarin and Abd-Allah (2006) in Washington Naval Orange.

The data in (Table 2) reveal that interaction effect of calcium nitrate, boric acid and zinc sulphate was significant on number of segments per fruit. The maximum number of segments per fruit (12.56) was recorded with treatment $\mathrm{T}_{24}$ (calcium nitrate 3.0 per cent + boric acid 0.4 per cent + zinc sulphate 0.6 per cent) which was closely followed by $\mathrm{T}_{23}, \mathrm{~T}_{27}$ , $\mathrm{T}_{21}$ and $\mathrm{T}_{26}$ treatments. However, the minimum number of number of segments per fruit (9.00) was recorded in control. The variation in the number of segments per fruit due to combination of different micronutrients might be attributed to difference in enzyme ion alluding during cell division and cell differentiation phases of fruit developments. The present results are in conformity with the findings of Razzaq et al. (2013) in Kinnow and Khan et al. 2015 in Kinnow.

The maximum number of fruits per plant (134.43) was recorded with treatment $\mathrm{T}_{27}$ (calcium nitrate $3.0 \%+$ boric acid $0.6 \%+$ zinc sulphate $0.6 \%$ ) treatments. (Table 2 ) It was closely followed by $\mathrm{T}_{24}, \mathrm{~T}_{26}$ and $\mathrm{T}_{23}$ treatments. However, the minimum number of fruits per plant (97.67) was recorded in control. The increase in number of fruits by application of micronutrient treatments may be due to reduction in fruit drop as a result of zinc, boron and calcium application which resulted in higher number of fruits and consequently the yield. The present results are in conformity with the findings of Haque et al. (2000) in mandarin, Babu et al. (2007) in Kinnow mandarin and Razzaq et al. (2013) in kinnow. 
Table: 1 Effect of pre-harvest spray of calcium nitrate, boric acid and zinc sulphate on physical characteristics of Nagpur mandarin (Citrus reticulata Blanco)

\begin{tabular}{|c|c|c|c|c|c|c|}
\hline \multirow{2}{*}{\multicolumn{2}{|c|}{ Treatments }} & \multirow{2}{*}{\multicolumn{2}{|c|}{ Diameter of fruits $(\mathrm{cm})$}} & \multirow{3}{*}{$\begin{array}{c}\begin{array}{c}\text { Peel } \\
\text { Thickness (mm) }\end{array} \\
4.86 \\
\end{array}$} & \multirow{3}{*}{$\begin{array}{c}\begin{array}{c}\text { Fruit weight } \\
(\mathrm{g})\end{array} \\
113.61 \\
\end{array}$} & \multirow{3}{*}{$\begin{array}{c}\begin{array}{c}\text { Fruit volume } \\
(\mathrm{cc})\end{array} \\
138.03 \\
\end{array}$} \\
\hline & & & & & & \\
\hline $\mathrm{T}_{0}$ & $\mathrm{Ca}_{0} \mathrm{~B}_{0} \mathrm{Zn}_{0}$ & $\begin{array}{c}\text { Horizontal } \\
6.11 \\
\end{array}$ & $\begin{array}{r}\text { Vertical } \\
5.18 \\
\end{array}$ & & & \\
\hline $\mathrm{T}_{1}$ & $\mathrm{Ca}_{1} \mathrm{~B}_{1} \mathrm{Zn}_{1}$ & 6.22 & 5.56 & 4.78 & 122.67 & 148.79 \\
\hline $\mathrm{T}_{2}$ & $\mathrm{Ca}_{1} \mathrm{~B}_{1} \mathrm{Zn}_{2}$ & 6.48 & 5.65 & 4.52 & 125.83 & 149.45 \\
\hline $\mathrm{T}_{3}$ & $\mathrm{Ca}_{1} \mathrm{~B}_{1} \mathrm{Zn}_{3}$ & 6.58 & 5.78 & 4.39 & 130.53 & 152.82 \\
\hline $\mathrm{T}_{4}$ & $\mathrm{Ca}_{1} \mathrm{~B}_{2} \mathrm{Zn}_{1}$ & 6.80 & 5.82 & 3.97 & 132.34 & 160.00 \\
\hline $\mathrm{T}_{5}$ & $\mathrm{Ca}_{1} \mathrm{~B}_{2} \mathrm{Zn}_{2}$ & 6.79 & 5.98 & 4.29 & 129.28 & 156.29 \\
\hline $\mathrm{T}_{6}$ & $\mathrm{Ca}_{1} \mathrm{~B}_{2} \mathrm{Zn}_{3}$ & 6.85 & 5.60 & 3.82 & 138.30 & 156.24 \\
\hline $\mathrm{T}_{7}$ & $\mathrm{Ca}_{1} \mathrm{~B}_{3} \mathrm{Zn}_{1}$ & 6.92 & 5.98 & 3.83 & 140.11 & 170.16 \\
\hline $\mathrm{T}_{8}$ & $\mathrm{Ca}_{1} \mathrm{~B}_{3} \mathrm{Zn}_{2}$ & 6.66 & 6.02 & 3.79 & 130.22 & 157.82 \\
\hline $\mathrm{T}_{9}$ & $\mathrm{Ca}_{1} \mathrm{~B}_{3} \mathrm{Zn}_{3}$ & 7.12 & 6.44 & 3.53 & 140.08 & 168.55 \\
\hline $\mathrm{T}_{10}$ & $\mathrm{Ca}_{2} \mathrm{~B}_{1} \mathrm{Zn}_{1}$ & 6.88 & 6.34 & 3.72 & 147.98 & 173.22 \\
\hline $\mathrm{T}_{11}$ & $\mathrm{Ca}_{2} \mathrm{~B}_{1} \mathrm{Zn}_{2}$ & 6.94 & 5.95 & 3.69 & 140.12 & 167.45 \\
\hline $\mathrm{T}_{12}$ & $\mathrm{Ca}_{2} \mathrm{~B}_{1} \mathrm{Zn}_{3}$ & 7.38 & 6.42 & 3.77 & 141.36 & 171.32 \\
\hline $\mathrm{T}_{13}$ & $\mathrm{Ca}_{2} \mathrm{~B}_{2} \mathrm{Zn}_{1}$ & 7.41 & 6.54 & 3.78 & 148.97 & 175.22 \\
\hline $\mathrm{T}_{14}$ & $\mathrm{Ca}_{2} \mathrm{~B}_{2} \mathrm{Zn}_{2}$ & 7.43 & 6.76 & 3.74 & 139.32 & 171.11 \\
\hline $\mathrm{T}_{15}$ & $\mathrm{Ca}_{2} \mathrm{~B}_{2} \mathrm{Zn}_{3}$ & 7.39 & 6.38 & 3.66 & 150.19 & 178.82 \\
\hline $\mathrm{T}_{16}$ & $\mathrm{Ca}_{2} \mathrm{~B}_{3} \mathrm{Zn}_{1}$ & 7.48 & 6.85 & 3.67 & 142.78 & 167.17 \\
\hline $\mathrm{T}_{17}$ & $\mathrm{Ca}_{2} \mathrm{~B}_{3} \mathrm{Zn}_{2}$ & 7.52 & 7.05 & 3.65 & 151.07 & 178.33 \\
\hline $\mathrm{T}_{18}$ & $\mathrm{Ca}_{2} \mathrm{~B}_{3} \mathrm{Zn}_{3}$ & 7.11 & 6.92 & 3.50 & 144.83 & 176.12 \\
\hline $\mathrm{T}_{19}$ & $\mathrm{Ca}_{3} \mathrm{~B}_{1} \mathrm{Zn}_{1}$ & 7.53 & 6.22 & 3.57 & 153.42 & 183.11 \\
\hline $\mathrm{T}_{20}$ & $\mathrm{Ca}_{3} \mathrm{~B}_{1} \mathrm{Zn}_{2}$ & 7.42 & 7.08 & 3.67 & 150.99 & 178.31 \\
\hline $\mathrm{T}_{21}$ & $\mathrm{Ca}_{3} \mathrm{~B}_{1} \mathrm{Zn}_{3}$ & 7.70 & 7.23 & 3.67 & 145.54 & 176.23 \\
\hline $\mathrm{T}_{22}$ & $\mathrm{Ca}_{3} \mathrm{~B}_{2} \mathrm{Zn}_{1}$ & 7.77 & 7.27 & 3.38 & 147.44 & 176.57 \\
\hline $\mathrm{T}_{23}$ & $\mathrm{Ca}_{3} \mathrm{~B}_{2} \mathrm{Zn}_{2}$ & 7.83 & 7.47 & 3.57 & 157.33 & 187.34 \\
\hline $\mathrm{T}_{24}$ & $\mathrm{Ca}_{3} \mathrm{~B}_{2} \mathrm{Zn}_{3}$ & 7.78 & 7.31 & 3.27 & 158.89 & 189.37 \\
\hline $\mathrm{T}_{25}$ & $\mathrm{Ca}_{3} \mathrm{~B}_{3} \mathrm{Zn}_{1}$ & 7.31 & 6.93 & 3.48 & 153.78 & 183.87 \\
\hline $\mathrm{T}_{26}$ & $\mathrm{Ca}_{3} \mathrm{~B}_{3} \mathrm{Zn}_{2}$ & 7.82 & 7.44 & 3.33 & 157.33 & 187.86 \\
\hline $\mathrm{T}_{27}$ & $\mathrm{Ca}_{3} \mathrm{~B}_{3} \mathrm{Zn}_{3}$ & 7.89 & 7.58 & 3.21 & 160.72 & 190.14 \\
\hline & $5 \%$ & 0.14 & 0.16 & 0.07 & 2.73 & 3.75 \\
\hline & & 0.41 & 0.46 & 0.21 & 7.77 & 10.63 \\
\hline
\end{tabular}

Here,

Ca1 - Calcium nitrate- $1 \% \quad$ B1 - Boric acid $-0.2 \%, \quad$ Zn1 - Zinc sulphate $-0.2 \%$

$\mathrm{Ca} 2-$ Calcium nitrate $-2 \% \quad \mathrm{~B} 2-$ Boric acid $-0.4 \%, \quad \mathrm{Zn} 2-$ Zinc sulphate $-0.4 \%$

$\mathrm{Ca} 3-$ Calcium nitrate $-3 \% \quad \mathrm{~B} 3-$ Boric acid $-0.6 \%, \quad \mathrm{Zn} 3-$ Zinc sulphate $-0.6 \%$

Table 2 Effect of pre-harvest spray of calcium nitrate, boric acid and zinc sulphate on physical and quality attributes of Nagpur mandarin

\begin{tabular}{|c|c|c|c|c|c|c|}
\hline \multicolumn{2}{|c|}{ Treatments } & No. of seeds / fruit & No. of sacs / fruit & No. of fruits per plant & Yield per plant (kg) & $\begin{array}{c}\text { Estimated yield } \\
\text { (tones / ha.) }\end{array}$ \\
\hline $\mathrm{T}_{0}$ & $\mathrm{Ca}_{0} \mathrm{~B}_{0} \mathrm{Zn}_{0}$ & 9.89 & 9.00 & 97.67 & 11.27 & 3.55 \\
\hline $\mathrm{T}_{1}$ & $\mathrm{Ca}_{1} \mathrm{~B}_{1} \mathrm{Zn}_{1}$ & 9.78 & 9.89 & 100.33 & 12.06 & 3.69 \\
\hline $\mathrm{T}_{2}$ & $\mathrm{Ca}_{1} \mathrm{~B}_{1} \mathrm{Zn}_{2}$ & 9.78 & 9.67 & 107.00 & 12.11 & 3.77 \\
\hline $\mathrm{T}_{3}$ & $\mathrm{Ca}_{1} \mathrm{~B}_{1} \mathrm{Zn}_{3}$ & 9.42 & 9.89 & 109.00 & 12.33 & 3.94 \\
\hline $\mathrm{T}_{4}$ & $\mathrm{Ca}_{1} \mathrm{~B}_{2} \mathrm{Zn}_{1}$ & 9.67 & 10.33 & 108.00 & 13.77 & 4.02 \\
\hline $\mathrm{T}_{5}$ & $\mathrm{Ca}_{1} \mathrm{~B}_{2} \mathrm{Zn}_{2}$ & 9.67 & 10.11 & 110.67 & 15.22 & 4.14 \\
\hline $\mathrm{T}_{6}$ & $\mathrm{Ca}_{1} \mathrm{~B}_{2} \mathrm{Zn}_{3}$ & 9.23 & 10.78 & 118.00 & 14.33 & 4.24 \\
\hline $\mathrm{T}_{7}$ & $\mathrm{Ca}_{1} \mathrm{~B}_{3} \mathrm{Zn}_{1}$ & 8.94 & 10.44 & 117.67 & 15.78 & \\
\hline $\mathrm{T}_{8}$ & $\mathrm{Ca}_{1} \mathrm{~B}_{3} \mathrm{Zn}_{2}$ & 9.12 & 10.78 & 110.67 & 16.39 & 3.92 \\
\hline $\mathrm{T}_{9}$ & $\mathrm{Ca}_{1} \mathrm{~B}_{3} \mathrm{Zn}_{3}$ & 8.89 & 10.00 & 118.54 & 16.22 & 4.14 \\
\hline $\mathrm{T}_{10}$ & $\mathrm{Ca}_{2} \mathrm{~B}_{1} \mathrm{Zn}_{1}$ & 9.12 & 10.33 & 120.00 & 15.78 & \\
\hline $\mathrm{T}_{11}$ & $\mathrm{Ca}_{2} \mathrm{~B}_{1} \mathrm{Zn}_{2}$ & 8.89 & 10.78 & 121.33 & 17.34 & 4.62 \\
\hline $\mathrm{T}_{12}$ & $\mathrm{Ca}_{2} \mathrm{~B}_{1} \mathrm{Zn}_{3}$ & 9.00 & 11.11 & 118.33 & 17.77 & 4.42 \\
\hline $\mathrm{T}_{13}$ & $\mathrm{Ca}_{2} \mathrm{~B}_{2} \mathrm{Zn}_{1}$ & 8.78 & 10.67 & 125.33 & 17.92 & 4.77 \\
\hline $\mathrm{T}_{14}$ & $\mathrm{Ca}_{2} \mathrm{~B}_{2} \mathrm{Zn}_{2}$ & 8.50 & 11.44 & 119.00 & 17.11 & 4.64 \\
\hline $\mathrm{T}_{15}$ & $\mathrm{Ca}_{2} \mathrm{~B}_{2} \mathrm{Zn}_{3}$ & 8.24 & 10.89 & 119.00 & 18.37 & 4.96 \\
\hline $\mathrm{T}_{16}$ & $\mathrm{Ca}_{2} \mathrm{~B}_{3} \mathrm{Zn}_{1}$ & 8.37 & 11.78 & 120.00 & 18.44 & 5.27 \\
\hline
\end{tabular}


Table 2 Cont.

\begin{tabular}{|c|c|c|c|c|c|c|}
\hline \multicolumn{2}{|c|}{ Treatments } & \multirow{2}{*}{$\begin{array}{c}\text { No. of seeds / fruit } \\
8.10\end{array}$} & \multirow{2}{*}{$\begin{array}{c}\text { No. of sacs / fruit } \\
11.00\end{array}$} & \multirow{2}{*}{$\begin{array}{c}\text { No. of fruits per plant } \\
118.34\end{array}$} & \multirow{2}{*}{$\begin{array}{c}\text { Yield per plant }(\mathrm{kg}) \\
19.55\end{array}$} & \multirow{2}{*}{$\begin{array}{c}\begin{array}{c}\text { Estimated yield } \\
\text { (tones / ha.) }\end{array} \\
5.42 \\
\end{array}$} \\
\hline $\mathrm{T}_{17}$ & $\mathrm{Ca}_{2} \mathrm{~B}_{3} \mathrm{Zn}_{2}$ & & & & & \\
\hline $\mathrm{T}_{18}$ & $\mathrm{Ca}_{2} \mathrm{~B}_{3} \mathrm{Zn}_{3}$ & 7.96 & 11.78 & 125.67 & 19.78 & 5.74 \\
\hline $\mathrm{T}_{19}$ & $\mathrm{Ca}_{3} \mathrm{~B}_{1} \mathrm{Zn}_{1}$ & 8.10 & 10.89 & 121.34 & 19.04 & 5.82 \\
\hline $\mathrm{T}_{20}$ & $\mathrm{Ca}_{3} \mathrm{~B}_{1} \mathrm{Zn}_{2}$ & 7.78 & 11.67 & 121.67 & 18.99 & 5.94 \\
\hline $\mathrm{T}_{21}$ & $\mathrm{Ca}_{3} \mathrm{~B}_{1} \mathrm{Zn}_{3}$ & 7.44 & 12.00 & 125.00 & 20.33 & 6.04 \\
\hline $\mathrm{T}_{22}$ & $\mathrm{Ca}_{3} \mathrm{~B}_{2} \mathrm{Zn}_{1}$ & 7.67 & 11.78 & 128.23 & 20.11 & 5.85 \\
\hline $\mathrm{T}_{23}$ & $\mathrm{Ca}_{3} \mathrm{~B}_{2} \mathrm{Zn}_{2}$ & 7.67 & 12.33 & 130.78 & 21.10 & 6.18 \\
\hline $\mathrm{T}_{24}$ & $\mathrm{Ca}_{3} \mathrm{~B}_{2} \mathrm{Zn}_{3}$ & 6.33 & 12.56 & 132.33 & 21.48 & 6.28 \\
\hline $\mathrm{T}_{25}$ & $\mathrm{Ca}_{3} \mathrm{~B}_{3} \mathrm{Zn}_{1}$ & 7.78 & 11.44 & 128.67 & 20.77 & 6.11 \\
\hline $\mathrm{T}_{26}$ & $\mathrm{Ca}_{3} \mathrm{~B}_{3} \mathrm{Zn}_{2}$ & 7.14 & 11.89 & 131.11 & 21.37 & 6.23 \\
\hline $\mathrm{T}_{27}$ & $\mathrm{Ca}_{3} \mathrm{~B}_{3} \mathrm{Zn}_{3}$ & 6.82 & 12.22 & 134.43 & 21.67 & 6.32 \\
\hline \multicolumn{2}{|c|}{$\mathrm{CD}$ at $5 \%$} & 0.23 & 0.27 & 2.77 & 0.39 & 0.10 \\
\hline \multicolumn{2}{|c|}{$\operatorname{SEm} \pm$} & 0.65 & 0.76 & 7.87 & 1.11 & 0.31 \\
\hline
\end{tabular}

Here,

Ca1 - Calcium nitrate- $1 \%$

$\mathrm{Ca} 2-$ Calcium nitrate $-2 \%$

B1 - Boric acid $-0.2 \%, \quad$ Zn1 - Zinc sulphate $-0.2 \%$

B2 - Boric acid $-0.4 \%, \quad$ Zn2 - Zinc sulphate $-0.4 \%$

$\mathrm{Ca} 3-$ Calcium nitrate $-3 \% \quad \mathrm{~B} 3-$ Boric acid $-0.6 \%, \quad \mathrm{Zn} 3-$ Zinc sulphate $-0.6 \%$

The data in (table 4.2) indicated that the interaction effect of calcium nitrate, zinc sulphate and boric acid was significantly observed on fruit yield in $\mathrm{kg} /$ tree and tonnes/ ha.The fruit yield of Nagpur mandarin $(21.67 \mathrm{~kg} /$ tree and 6.32 tonnes/ha) recorded maximum with treatment $\mathrm{T}_{27}$ (calcium nitrate $3.0 \%+$ boric acid $0.6 \%+$ zinc sulphate $0.6 \%$ ) which was at par with $\mathrm{T}_{24,} \mathrm{~T}_{26}, \mathrm{~T}_{23}$ and $\mathrm{T}_{25}$ treatments. However, the minimum fruit yield $(11.27 \mathrm{~kg} /$ tree and 3.55 tonnes/ha) was recorded in control. The increase in yield of Nagpur mandarin fruits by application of micronutrient treatments may be due to the direct or indirect involvement of nutrients which provide better mobilization of nutrients and metabolites for the growth and development of fruits by increase in metabolic activities and better cellular pathways. These activities improve their size, weight and volume and thereby synergistically increased the total yield of Nagpur mandarin. The present results are in conformity with the findings of Saraswathi et al. (1998) in Mandarin and Patil et al. (2014) in Kinnow.

\section{Quality characteristics of fruits}

It is evident from the results that pre-harvest application of micronutrients on Nagpur mandarin had significantly improved the nutritional quality of fruits in terms of TSS, acidity content, TSS/Acid ratio, sugars contents, ascorbic acid content, juice per cent and sensory score of fruit as compared to control.

However, the highest TSS, $\left(12.05{ }^{\circ} \mathrm{B}\right)$, lowest acidity $(0.73 \%)$ and maximum TSS/ Acid ratio (15.97) were recorded under $\mathrm{T}_{24}$ (calcium nitrate 3.0 per cent + boric acid 0.4 per cent + zinc sulphate 0.6 per cent) treatment and $\mathrm{T}_{27}$ was found second best treatment with regards to these parameters (Table 3).

Higher total soluble solids and TSS: Acid ratio might be due to the efficient translocation of photosynthates to the fruit by regulation of calcium, boron and zinc. Ullah et al. (2012) revealed that acidity percentage of mandarin fruit might have been reduced due to higher synthesis of nucleic acids, on account of maximum availability of plant metabolism. The similar results of increase in TSS, reduction in acidity and there by increased TSS / acid ratio was observed by these micronutrient treatments by Dawood et al. (2002) in 'Balady' mandarin, El-Rahman (2003) in Naval orange and Prakash et al. (2014) in pomegranate.

The data presented in (Table 3) clearly indicates that the pre-harvest spray of calcium nitrate, boric acid and zinc sulphate had significantly increased the sugar content (Nonreducing and total sugar) of Nagpur mandarin fruits whereas, reducing sugar per cent was not observed significantly. In the present investigation of Nagpur mandarin, the highest reducing sugar $(6.30 \%)$, non-reducing $(2.58 \%)$ and total sugar content $(9.02 \%)$ were recorded with $\mathrm{T}_{27}$ (calcium nitrate 3 per cent + boric acid 0.6 per cent + zinc sulphate 0.6 per cent) treatment. Whereas, the minimum reducing sugar $(4.50 \%)$, non-reducing sugar $(1.72 \%)$ and total sugar $(6.31 \%)$ were recorded at control. The increase in sugars fraction by the foliar feeding of zinc and boron might be due to their involvement in photosynthesis of metabolites and rapid translocation of sugars from other part of the plants to developing fruits (Singh et al. 2012). These results are in conformity with the findings of Saraswathy et al. (1998) in Mandarin and Rajkumar et al. (2014) in Guava.

The data in (Fig 1) reveal that interaction effect of calcium nitrate, boric acid and zinc sulphate was significant on ascorbic acid of fruits. The ascorbic acid of Nagpur mandarin fruits $(50.61 \mathrm{mg} / 100 \mathrm{ml})$ was recorded maximum with treatment $\mathrm{T}_{24}$ (calcium nitrate 3.0 per cent + boric acid 0.4 per cent + zinc sulphate 0.6 per cent) which was closely followed by $\mathrm{T}_{27}, \mathrm{~T}_{23}, \mathrm{~T}_{26}, \mathrm{~T}_{18}, \mathrm{~T}_{20}$ and $\mathrm{T}_{21}$ treatments. However, minimum ascorbic acid of fruit $(34.95 \mathrm{mg})$ was recorded in control. Augmentation of ascorbic acid per cent age of mandarin fruit might be due to higher synthesis of nucleic 
acid, on account of maximum availability of plant metabolism (Sajid et al., (2012). These results are in conformity with the findings of Sajid et al. (2012) in Sweet orange and Yadav et al. (2015) in Guava.

The data in (Fig 1) reveal that the juice percent of Nagpur mandarin fruits (46.89) was recorded maximum with treatment $\mathrm{T}_{27}$ (calcium nitrate 3.0 per cent + boric acid 0.6 per cent + Zinc sulphate 0.6 per cent) which was closely followed by $\mathrm{T}_{24}, \mathrm{~T}_{23}, \mathrm{~T}_{25}, \mathrm{~T}_{26}$ and $\mathrm{T}_{21}$ treatments. However, the minimum juice percent of fruit $(32.43 \%)$ was recorded in control. These results are in close conformity with those of Dawood et al. (2002) in 'Balady' mandarin, Malik et al. (2000) in Kinnow and Prakash et al. (2014) in pomegranate.

The data in (Fig 1) reveal that interaction

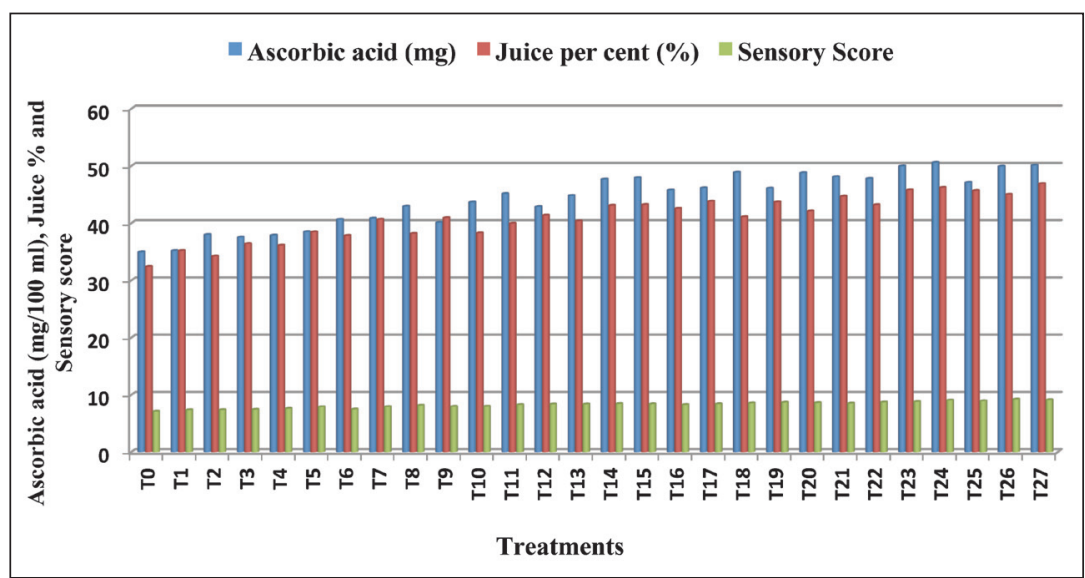

Figure 1 Interaction effect of pre harvest spray of calcium nitrate, boric acid and zinc sulphate on ascorbic acid (mg / $100 \mathrm{ml}$ juice ), Juice per cent and Sensory Score of Nagpur mandarin (Citrus reticulata Blanco) effect of calcium nitrate, boric acid and zinc sulphate was not significantly affected the sensory score of Mandarin fruits. However, the maximum sensory score $(9.23 / 10.00)$

was recorded with treatment $\mathrm{T}_{27}$ (calcium nitrate 3 per cent + boric acid 0.6 per cent + zinc sulphate 0.6 per cent). Whereas, the minimum sensory score of Mandarin (7.11/10.00) was recorded under control. The maximum organoleptic rating

Table 3 Effect of pre-harvest spray of calcium nitrate, boric acid and zinc sulphate on quality characteristics of Nagpur mandarin

\begin{tabular}{|c|c|c|c|c|c|c|c|}
\hline \multicolumn{2}{|c|}{ Treatments } & \multirow{2}{*}{$\begin{array}{c}\mathrm{TSS}\left({ }^{\circ} \mathrm{B}\right) \\
8.14 \\
\end{array}$} & \multirow{2}{*}{$\begin{array}{c}\text { T. Acidity (\%) } \\
0.98 \\
\end{array}$} & \multirow{2}{*}{$\begin{array}{c}\text { TSS/Acid ratio } \\
8.31 \\
\end{array}$} & \multirow{2}{*}{$\begin{array}{c}\begin{array}{c}\text { Reducing sugar } \\
(\%)\end{array} \\
4.50 \\
\end{array}$} & \multirow{2}{*}{$\begin{array}{c}\text { Non Reducing } \\
(\%)\end{array}$} & \multirow{2}{*}{$\begin{array}{c}\text { Total sugar } \\
(\%)\end{array}$} \\
\hline $\mathrm{T}_{0}$ & $\mathrm{Ca}_{0} \mathrm{~B}_{0} \mathrm{Zn}_{0}$ & & & & & & \\
\hline $\mathrm{T}_{1}$ & $\mathrm{Ca}_{1} \mathrm{~B}_{1} \mathrm{Zn}_{1}$ & 8.34 & 0.96 & 8.69 & 4.60 & 1.77 & 6.46 \\
\hline $\mathrm{T}_{2}$ & $\mathrm{Ca}_{1} \mathrm{~B}_{1} \mathrm{Zn}_{2}$ & 9.00 & 0.96 & 9.38 & 4.67 & 1.78 & 6.54 \\
\hline $\mathrm{T}_{3}$ & $\mathrm{Ca}_{1} \mathrm{~B}_{1} \mathrm{Zn}_{3}$ & 9.27 & 0.94 & 9.86 & 4.77 & 1.85 & 6.72 \\
\hline $\mathrm{T}_{4}$ & $\mathrm{Ca}_{1} \mathrm{~B}_{2} \mathrm{Zn}_{1}$ & 9.14 & 0.95 & 9.62 & 4.85 & 1.87 & 6.82 \\
\hline $\mathrm{T}_{5}$ & $\mathrm{Ca}_{1} \mathrm{~B}_{2} \mathrm{Zn}_{2}$ & 9.34 & 0.93 & 10.04 & 4.77 & 2.06 & 6.94 \\
\hline $\mathrm{T}_{6}$ & $\mathrm{Ca}_{1} \mathrm{~B}_{2} \mathrm{Zn}_{3}$ & 10.13 & 0.90 & 11.26 & 4.89 & 2.13 & 7.13 \\
\hline $\mathrm{T}_{7}$ & $\mathrm{Ca}_{1} \mathrm{~B}_{3} \mathrm{Zn}_{1}$ & 9.74 & 0.88 & 11.07 & 4.98 & 2.22 & 7.32 \\
\hline $\mathrm{T}_{8}$ & $\mathrm{Ca}_{1} \mathrm{~B}_{3} \mathrm{Zn}_{2}$ & 10.24 & 0.88 & 11.64 & 5.02 & 2.15 & 7.28 \\
\hline $\mathrm{T}_{9}$ & $\mathrm{Ca}_{1} \mathrm{~B}_{3} \mathrm{Zn}_{3}$ & 10.27 & 0.85 & 12.08 & 5.11 & 2.10 & 7.32 \\
\hline $\mathrm{T}_{10}$ & $\mathrm{Ca}_{2} \mathrm{~B}_{1} \mathrm{Zn}_{1}$ & 10.34 & 0.89 & 11.62 & 5.20 & 2.11 & 7.42 \\
\hline $\mathrm{T}_{11}$ & $\mathrm{Ca}_{2} \mathrm{~B}_{1} \mathrm{Zn}_{2}$ & 10.62 & 0.86 & 12.35 & 5.30 & 2.25 & 7.67 \\
\hline $\mathrm{T}_{12}$ & $\mathrm{Ca}_{2} \mathrm{~B}_{1} \mathrm{Zn}_{3}$ & 10.76 & 0.85 & 12.66 & 5.46 & 2.14 & 7.71 \\
\hline $\mathrm{T}_{13}$ & $\mathrm{Ca}_{2} \mathrm{~B}_{2} \mathrm{Zn}_{1}$ & 10.84 & 0.82 & 13.22 & 5.50 & 2.30 & 7.92 \\
\hline $\mathrm{T}_{14}$ & $\mathrm{Ca}_{2} \mathrm{~B}_{2} \mathrm{Zn}_{2}$ & 11.11 & 0.82 & 13.55 & 5.61 & 2.31 & 8.04 \\
\hline $\mathrm{T}_{15}$ & $\mathrm{Ca}_{2} \mathrm{~B}_{2} \mathrm{Zn}_{3}$ & 11.37 & 0.80 & 14.21 & 5.56 & 2.26 & 7.94 \\
\hline $\mathrm{T}_{16}$ & $\mathrm{Ca}_{2} \mathrm{~B}_{3} \mathrm{Zn}_{1}$ & 11.67 & 0.78 & 14.96 & 5.67 & 2.32 & 8.11 \\
\hline $\mathrm{T}_{17}$ & $\mathrm{Ca}_{2} \mathrm{~B}_{3} \mathrm{Zn}_{2}$ & 11.67 & 0.79 & 14.77 & 5.77 & 2.34 & 8.23 \\
\hline $\mathrm{T}_{18}$ & $\mathrm{Ca}_{2} \mathrm{~B}_{3} \mathrm{Zn}_{3}$ & 11.78 & 0.77 & 15.30 & 5.81 & 2.38 & 8.31 \\
\hline $\mathrm{T}_{19}$ & $\mathrm{Ca}_{3} \mathrm{~B}_{1} \mathrm{Zn}_{1}$ & 11.05 & 0.80 & 13.81 & 6.11 & 2.26 & 8.49 \\
\hline $\mathrm{T}_{20}$ & $\mathrm{Ca}_{3} \mathrm{~B}_{1} \mathrm{Zn}_{2}$ & 11.78 & 0.79 & 14.91 & 6.20 & 2.35 & 8.67 \\
\hline $\mathrm{T}_{21}$ & $\mathrm{Ca}_{3} \mathrm{~B}_{1} \mathrm{Zn}_{3}$ & 11.85 & 0.77 & 15.39 & 6.11 & 2.54 & 8.78 \\
\hline $\mathrm{T}_{22}$ & $\mathrm{Ca}_{3} \mathrm{~B}_{2} \mathrm{Zn}_{1}$ & 11.78 & 0.78 & 15.10 & 6.24 & 2.44 & 8.81 \\
\hline $\mathrm{T}_{23}$ & $\mathrm{Ca}_{3} \mathrm{~B}_{2} \mathrm{Zn}_{2}$ & 11.85 & 0.76 & 15.59 & 6.29 & 2.52 & 8.94 \\
\hline $\mathrm{T}_{24}$ & $\mathrm{Ca}_{3} \mathrm{~B}_{2} \mathrm{Zn}_{3}$ & 12.05 & 0.73 & 15.97 & 6.23 & 2.54 & 8.90 \\
\hline $\mathrm{T}_{25}$ & $\mathrm{Ca}_{3} \mathrm{~B}_{3} \mathrm{Zn}_{1}$ & 11.90 & 0.77 & 15.56 & 6.22 & 2.51 & 8.86 \\
\hline $\mathrm{T}_{26}$ & $\mathrm{Ca}_{3} \mathrm{~B}_{3} \mathrm{Zn}_{2}$ & 11.98 & 0.76 & 15.65 & 6.28 & 2.57 & 8.98 \\
\hline $\mathrm{T}_{27}$ & $\mathrm{Ca}_{3} \mathrm{~B}_{3} \mathrm{Zn}_{3}$ & 12.00 & 0.74 & 15.78 & 6.30 & 2.58 & 9.02 \\
\hline \multicolumn{2}{|c|}{$\mathrm{CD}$ at $5 \%$} & 0.12 & 0.01 & 0.18 & 0.06 & 0.02 & 0.08 \\
\hline \multicolumn{2}{|c|}{$\mathrm{SEm} \pm$} & 0.26 & NS & 0.40 & NS & 0.08 & 0.16 \\
\hline
\end{tabular}


due to application of calcium, zinc and boron might be due to better sugar acid ratio and better electrolytic balance of juice and overall enhancement of fruit quality. These results are in close conformity with those of Malik et al. (2000) in Kinnow, El-Rahman (2003) in Naval orange.

\section{Conclusion}

On the basis of results obtained from the field experiment, it may be concluded that the pre-harvest spray of different micronutrients was found beneficial for yield and quality of Nagpur mandarin especially under Agro-climatic zone-V of Rajasthan i.e. in Jhalawar condition. However, among different interaction treatments, $\mathrm{T}_{27}$ treatment (calcium nitrate $3 \%+$ boric acid $0.6 \%+$ zinc sulphate $0.6 \%$ ) has given significantly maximum increase diameter of fruit, fruit weight, fruit volume, number of fruits per plant, fruit yield per plant, estimated yield per hectare, reducing sugar, non reducing sugar, total sugar, juice per cent, sensory score and reduced peel thickness over control. Further, $\mathrm{T}_{24}$ treatment combination (calcium nitrate $3 \%+$ boric acid $0.4 \%+$ zinc sulphate $0.6 \%$ ) has also significantly increased number of segments per fruit, TSS, TSS: Acid ratio, ascorbic acid content, and reduced number of seeds per fruit and acidity percent of fruits.

\section{References}

A.O.A.C. (2007) Official Method of Analysis. 15 $5^{\text {th }}$ Ed. Vol II. Association of Official Analytical Chemists. Washington, D.C.

Abd-Allah, A. S. (2006) Effect of spraying some macro and micro nutrients on fruit set, yield and fruit quality of Washington Navel orange trees. Journal of Applied Sciences Research, 2(11):1059-1063

Anonymous (2015) Indian Horticulture Database, 2014. Published From National Horticulture Board, Gurgaon, pp.118-121.

Anonymous (2015) Assistant Director Horticulture, Department of Horticulture Jhalawar. pp 2.

Babu, K.D., Dubey, A.K. and Yadav, D.S. (2007) Effect of micronutrients on enhancing the productivity and quality of kinnow mandarin. Indian Journal of Horticulture, 64(3): 353-356.

Chaturvedi, R.S., Gaur, O. P. and Singh, G. (2007) Effect of preharvest spray of zinc, calcium and boron on the storage behaviour of guava (Psidium guajava L.) fruits cv. Allahabad Safeda. Acta Horticulturae; 7 (35): 633-638

Dawood, S. A., Meligy, M. S. and El-Hamady, M. M. (2002) Influence of pre harvest spray of calcium nitrate, zinc

sulphate and boric acid on quality and shelf life of Balady mandarin. Annals of Agricultural Science, 39(1): 433-447

El-Rahman, A.M.A. (2003) Effects of some nutrients and growth substances application on fruiting, yield and fruit quality of Navel orange trees. Bulletin of Faculty of Agriculture, Cairo University, 54 (2): 175-187

Fisher, R.A., (1950) Statistical methods for research workers. Oliver and Boyd, Edinburgh

Haque, R., Roy, A. and Pramanick, M. (2000) Response of foliar application of $\mathrm{Ca}, \mathrm{Zn}$, and $\mathrm{B}$ on improvement of growth, yield and quality of mandarin orange in Darjeeling hills of West Bengal. Horticultural Journal, 13 (2):15-20

Holb IJ, Balla B, Vámos A, Gáll JM (2012) Influence of preharvest calcium applications, fruit injury, and storage atmospheres on postharvest brown rot of apple. Postharvest Biology and Technology 67: 29-36.

Katiyar, P. N., Singh, J.P and Singh, P.C. (2008) Effect of zinc sulphate, borax and calcium nitrate in flowering, fruiting, yield and quality of Litchi cv. Dehradun. Journal of Rural and Agricultural Research, 8 (2): 49-51

Khan, A. S., Nasir, M., Malik, A.U., Basra, S.M.A. and Jaskani, M. J. (2015) Effect of calcium, boron and zinc on the leaf mineral status, growth, productivity and fruit quality of 'Kinnow' mandarin (Citrus nobilis Lour x Citrus deliciosa Tenora). Journal of Plant Nutrition, 38 (6):821-838.

Meena, D. Tiwari, R. and Singh, O.P. (2014) Effect of nutrient spray on growth, fruit yield and quality of aonla. Annals of Plant and Soil Research, 16 (3): 242-245

Malik, R.P., Ahlawat, V.P. and Nain, A.S. (2000) Effect of foliar spray of urea and zinc sulphate on yield and fruit quality of kinnowmandarin hybrid. Haryana Journal of Horticultural Science, 29 (12): 37-38.

Patil, M.S., Shafeeq, L. B. and Swamy, G. S. K. (2014) Studies on the influence of micronutrient on growth, yield and quality of Kinnow mandarin. Trends in Biosciences, 7 (9): 786-788.

Prakash, K., Ponnuswami, V. and Kulkarni, D. N. (2014) Effect of pre-harvest chemical spray on quality of pomegranate (Punica granatum L.) cv. Bahgwa. Trends in Biosciences, 7 (11): 1090-1092.

Rajkumar, Tiwari, J.P. and Shant, Lal. (2014) Effect of foliar application of zinc and boron on fruit yield and quality of winter season guava (Psidium guajava) cv. Pant Prabhat. Annals of Agric. Biol. Res. 19 (1): 105-108.

Razzaq, K., Khan, A.S., Malik, A.U., Shahid, M. and Ullah, S. (2013) Foliar application of zinc influences the leaf mineral status, vegetative and reproductive growth, and yield and fruit quality of 'kinnow' mandarin. Journal of Plant Nutrition, 36 (10): 1479-1495.

Sajid, M., Rab, A., Tanveer, S., Iqbal, A., Zamin, M. and Shakur, M. (2012) Pre-harvest treatment of $Z n \&$ B affects the fruit quality and storability of sweet orange. J. Agric. Sci. and Technol., 2 (2):1224-1233

Saraswathi T., Thangaraj T., Azhakiamanavalan R.S. and Balakrishnamurthy G. (1998) Effect of micro-nutrients on yield and quality of Mandarin (Citrus reticulata Blanco). South Indian Horticulture 46(3-4): 128- 131.

Singh, P. C. Gangwar, R. S. and Singh, V. K. (2012) Effect of micronutrients spray on fruit drop, fruit quality and yield of aonla cv. Banarasi. Hort Flora Research Spectrum, 1(1):73-76

Tariq, M., Sharif, M., and Khan, R. (2007) Effect of foliar spray of micronutrients on the yield and quality of sweet orange (Citrus sinensis L.) Pak. Journal of biological Science, 10 (11): 1823-1828.

Ullah, S., Khan, A.S., Malik, A.U., Afzal, I., Shahid, M. and Razzaq, K. (2012) Foliar application of boron influences the leaf mineral status, vegetative and reproductive growth, yield and fruit quality of 'kinnow' mandarin ( Blanco.). Journal of Plant Nutrition, 35 (13): 2067-2079.

Yadav, R. K., Ram, R. B., Meena, M. L., Kumar, V. and Singh, H. D. (2015) Response of foliar spray of micronutrients on fruit set, yield and quality of winter season guava ( L.) cv. Allahabad Safeda. Environment and Ecology, 33(1): 444-447. 